\title{
Polysomnographic and clinical characteristics of positional obstructive sleep apnea patients
}

\author{
Seda Beyhan Sagmen* (iD and Sevda Cömert
}

\begin{abstract}
Background: Obstructive sleep apnea is a condition characterized by the complete or partial obstruction of the upper airway during sleep. This study aimed to compare the clinical and polysomnographic characteristics of our obstructive sleep apnea patients according to their positional and non-positional features.

Results: Two hundred eighty patients were included in the study. One hundred two patients (36.43\%) were female, while 178 patients (63.57\%) were male. While 88 (31.43\%) of these patients were defined as positional patients, 192 (68.57\%) were defined as non-positional patients. The mean age of the positional patients (46.78 \pm 9.66$)$ was lower than the mean age of the non-positional patients (50.90 \pm 10.96$)$ ( $p$ 0.001). Similarly, the mean body mass index of the positional patients $(29.39 \pm 3.80)$ was lower than the mean body mass index of the non-positional patients $(33.30 \pm 6.45)(p<0.001)$. Neck circumference values of the positional patients $(40.36 \pm 2.65)$ were lower compared to the non-positional patients $(43.32 \pm 2.54)(p<0.001)$.

Sleep values were compared based on the presence of positional sleep apnea. In the positional patients, sleep duration, sleep efficiency (percentage), duration of stage N3, minimum, and mean saturation values were found to be higher compared to the non-positional patients, while nightlong apnea hypopnea index, apnea index, percentage of sleep time with oxygen saturation below 90\%, oxygen desaturation index, mean heart rate, and periodic limb movement index values were found to be lower $(p<0.05)$.

The rate of severe sleep apnea $(7.95 \%)$ in the positional patients was lower than the non-positional patients $(53.65 \%)(p<0.001)$.

Conclusion: In the light of these data, positional OSA is a very important condition presented in $31.43 \%$ of OSA patients and it was determined that these patients were younger, had less body mass index, and shorter neck circumference. The rate of severe disease was found to be lower in positional OSA patients
\end{abstract}

Keywords: Positional obstructive sleep apnea, Age, Body mass index, Severity disease, Polysomnography

\section{Background}

Obstructive sleep apnea syndrome (OSA), which is observed at the rate of $2-4 \%$ in the general population, is a chronic and complex clinical syndrome characterized by snoring, periodic apnea, hypoxemia during sleep, and excessive daytime sleepiness [1,2]. Physiological changes that emerge as a result of recurrent apneas cause the

\footnotetext{
* Correspondence: sedabeyhansagmen@gmail.com

Department of Pulmonary Medicine, Health Science Unv Kartal Dr. Lütfi Kirdar Training and Research Hospital, Bostanci, Istanbul, Turkey
}

development of pulmonary, metabolic, and neurological diseases, especially cardiovascular diseases [3].

Abnormalities in the pharynx anatomy, physiology of the upper respiratory tract dilator muscles, and stability of respiratory control are important causes of recurrent pharyngeal collapse during sleep [2]. However, this event occurring with a complex structural and neuromuscular interaction is still not fully known [4]. Factors reducing the width of the upper respiratory tract and facilitating the collapse increase the tendency towards OSA. Known

\section{Springer Open}

(๑) The Author(s). 2021 Open Access This article is licensed under a Creative Commons Attribution 4.0 International License, which permits use, sharing, adaptation, distribution and reproduction in any medium or format, as long as you give appropriate credit to the original author(s) and the source, provide a link to the Creative Commons licence, and indicate if changes were made. The images or other third party material in this article are included in the article's Creative Commons licence, unless indicated otherwise in a credit line to the material. If material is not included in the article's Creative Commons licence and your intended use is not permitted by statutory regulation or exceeds the permitted use, you will need to obtain permission directly from the copyright holder. To view a copy of this licence, visit http://creativecommons.org/licenses/by/4.0/. 
major risk factors for OSA include advanced age, male gender, obesity, short and thick neck structure, smoking, alcohol, and sedative drug use [5].

Sleeping position is a mechanical factor that may contribute to the development of OSA. In individuals with and without apnea, the airway cross-sectional area significantly reduces in the supine position, which can cause OSA [6]. The severity of breathing abnormalities in the general OSA population is generally associated with body position during sleep. The supine position increases the number and severity of apnea events and affects the emergence of respiratory disorder. During all stages of sleep, upper airway collapse is higher in the supine position compared to the lateral position. Positional OSA occurs when apnea hypopnea index (AHI) in the supine position is two times higher than AHI in the lateral position [7]. The absence of upper respiratory tract obstruction in the side-lying position or significantly less than obstruction in the supine position in some patients suggests that some characteristics of these patients are different [4]. A study revealed that there were fewer and less severe respiratory abnormalities in the positional OSA group compared to the nonpositional OSA group, and it was observed to have an inversely proportional relationship with body mass index (BMI) and age [8]. In recent years, it is important to define different clinical types of sleep apnea and to determine appropriate treatment approaches. However, there were not enough studies about positional OSA. In this study, it was aimed to investigate the possible clinical and polysomnographic differences in the patients with positional OSA and patients with non-positional OSA.

\section{Methods}

The files of 310 patients diagnosed with OSA in the sleep clinic of our hospital between 2017 and 2018 were evaluated retrospectively. Thirty patients, who had cardiac failure, were diagnosed with central sleep apnea and had lung disease affecting oxygen saturation, were excluded from the study. The patients' symptoms, age, gender, Epworth Sleepiness Scale score, neck circumference measured from the cricoid cartilage level in the sitting position, body mass index, arterial blood gas, and additional diseases were recorded. The polysomnographic records of the patients were examined, and polysomnographic findings such as total sleep duration, sleep efficiency, sleep latency, sleep stages, AHI, apnea index (AI), AHI in the supine and lateral position, minimum oxygen saturation, mean oxygen saturation, oxygen desaturation index (ODI), percent sleep time spent with oxygen saturation $<90 \%$ (TST 90), and periodic limb movement index (PLM) were recorded.

\section{Polysomnography}

During the polysomnography (PSG)(Comet Grass: Astro-Med, Inc., West Warwick, Rhode Island, USA) examination, electroencephalogram (EEG) (C3-A2, C4$\mathrm{A} 1, \mathrm{O} 1-\mathrm{A} 2$, and F4-A1), 2-channel electroculogram (EOG), electrocardiogram (ECG), electromyogram (EMG) recording, oronasal airflow, thoracic and abdominal movements, body position, oxygen saturation measurement from fingertip with pulse oximeter, and microphone for snoring were performed. The cases with AHI $\geq 5$ event/h were defined as OSA. AHI value was calculated according to apnea and hypopnea. The patients with AHI: $5-15$ were accepted as mild OSA, AHI: 15-30 moderate OSA, and AHI $\geq 30$ severe OSA. The diagnosis of positional OSA was established in a patient diagnosed with Obstructive Sleep Apnea (Total AHI > 5), on the condition that the non-supine AHI was within normal limits, and supine AHI was at least twice or more than non-supine-AHI [9].

\section{Statistical analyses}

Statistical analyses were performed by using the SPSS version 17.0 program. The suitability of the variables for normal distribution was examined with histogram graphs and the Kolmogorov-Smirnov test. Mean, standard deviation, median, and min-max values were used when presenting descriptive analyses. In $2 \times 2$ cells, they were compared with Pearson's chi-squared and Fisher's exact tests. While evaluating the nonparametric variables in paired groups, Mann-Whitney $U$ test was used. While comparing the variables that did not show the normal distribution in triple groups, the Kruskal-Wallis test was used. In the analysis of the measurement data within each other, the Spearman correlation test was used. Conditions with a $p$ value below 0.05 were accepted as statistically significant results.

\section{Results}

Two hundred eighty patients were included in the study. One hundred two patients $(36.43 \%)$ were female, while 178 patients $(63.57 \%)$ were male. While $88(31.43 \%)$ of these patients were defined as positional patients, 192 $(68.57 \%)$ were defined as non-positional patients. Snoring was seen in $277(98.93 \%)$ of the patients, witness apnea in 229 (81.79\%), daytime sleepiness in 199 (71.07\%), morning headache in $72(25.71 \%)$, and night sweating in 31 (11.07\%). The mean age of the positional patients $(46.78 \pm 9.66)$ was found to be lower than the mean age of the non-positional patients $(50.90 \pm 10.96)$ ( $p: 0.001)$. Similarly, the mean BMI of the positional patients $(29.39 \pm 3.80)$ was found to be lower than the mean BMI of the non-positional patients $(33.30 \pm 6.45)$ $(p<0.001)$. The neck circumference of the positional patients $(40.36 \pm 2.65)$ was found to be lower than the 
neck circumference of the non-positional patients (43.32 $\pm 2.54)(p<0.001)$. No significant difference was found between the positional and non-positional patients in terms of gender.

Sleep values were compared based on the presence of positional sleep apnea. In the positional patients, sleep duration, sleep efficiency (percentage), duration of stage $\mathrm{N} 3$, minimum, and mean saturation values were found to be higher compared to the non-positional patients, while nightlong AHI, AI (apnea index), percentage of sleep time with oxygen saturation below $90 \%$, sleep ODI, mean heart rate, and PLM index values were found to be lower $(p<0.05)$ (Table 1$)$.

The rate of severe sleep apnea (7.95\%) in the positional patients was lower than the non-positional patients (53.65\%) $(p<0.001)$ (Fig. 1).

Comorbidities were compared based on the presence of positional sleep apnea. The rate of hypertension (HT) in the positional patients (25\%) was found to be lower than the rate of $\mathrm{HT}$ in the non-positional patients $(38.02 \%)$ ( $p: 0.033)$. The rate of hypothyroidism in the positional patients $(1.14 \%)$ was lower than the nonpositional patients $(6.77 \%)$ ( $p: 0.045)$.The rate of diabetes mellitus (DM) in the positional patients (13.64\%) was lower compared to the non-positional patients (23.96\%) ( $p: 0.048)$. There was no significant difference between the two groups in terms of the other comorbidities $(p>$ 0.05).

The mean partial pressure of oxygen (pO2) (91.26 \pm 19.29) of the positional patients in blood gas analysis was higher than the pO2 $(85.21 \pm 17.63)$ of the nonpositional patients $(p: 0.030)$. Similarly, the mean oxygen saturation $(\mathrm{sO} 2)(96.83 \pm 2.80)$ of the positional patients was higher than the $\mathrm{sO} 2(95.63 \pm 3.81)$ of the nonpositional patients $(p: 0.001)$.

\section{Discussion}

In this study, where the clinical and polysomnographic characteristics of the patients with positional OSA were examined, it was found that the positional group was younger, had less BMI, and shorter neck circumference. Additional diseases such as HT and DM were less observed in the positional group.

In studies examining the positional OSA rate in the world, the positional OSA rate varies between $27.4 \%$ and $70 \%$ [10-12]. In a study conducted in 2011 on 230

Table 1 Demographic and polysomnographic characteristics of OSA patients

\begin{tabular}{|c|c|c|c|}
\hline & $\begin{array}{l}\text { Non-POSA } \\
(n=192)\end{array}$ & $\begin{array}{l}\text { POSA } \\
(n=88)\end{array}$ & $p$ value \\
\hline Age (years) & $50.9 \pm 10.96$ & $46.78 \pm 9.66$ & $<0.001$ \\
\hline Female/male & 75 (39\%)/117 (61\%) & $27(31 \%) / 61(69 \%)$ & 0.176 \\
\hline BMI $\left(\mathrm{kg} / \mathrm{m}^{2}\right)$ & $33.3 \pm 6.45$ & $29.39 \pm 3.80$ & $<0.001$ \\
\hline Epworth Sleepiness Scale score & $8.44 \pm 6.21$ & $7.74 \pm 5.19$ & 0.655 \\
\hline Total recording time(min) & $389.38 \pm 88.83$ & $422.40 \pm 30.59$ & 0.001 \\
\hline Total sleep time(min) & $296.09 \pm 94.12$ & $348.68 \pm 63.44$ & $<0.001$ \\
\hline Sleep efficiency (\%) & $80.46 \pm 51.90$ & $82.26 \pm 12.95$ & $<0.001$ \\
\hline Sleep latency (min) & $31.42 \pm 27.69$ & $30.39 \pm 36.32$ & 0.145 \\
\hline REM latency (min) & $132.54 \pm 82.46$ & $118.73 \pm 63.27$ & 0.312 \\
\hline Total apnea hypopnea index & $39.99 \pm 27.52$ & $15.56 \pm 10.61$ & $<0.001$ \\
\hline Apnea index & $26.55 \pm 27.95$ & $8.81 \pm 12.35$ & $<0.001$ \\
\hline Supine apnea hypopnea index & $53.41 \pm 35.57$ & $32.72 \pm 21.49$ & $<0.001$ \\
\hline Non supine apnea hypopnea index & $30.44 \pm 28.94$ & $3.40 \pm 3.72$ & $<0.001$ \\
\hline sleep time with oxygen saturation below $90 \%$ (TST90) & $26.38 \pm 32.20$ & $6.74 \pm 13.74$ & $<0.001$ \\
\hline Oxygen desaturation index & $35.32 \pm 27.27$ & $12.18 \pm 10.72$ & $<0.001$ \\
\hline Minimum saturation (\%) & $76.91 \pm 11.91$ & $84.97 \pm 6.37$ & $<0.001$ \\
\hline Mean saturation (\%) & $91.13 \pm 4.58$ & $93.88 \pm 1.73$ & $<0.001$ \\
\hline Mean heart rate & $69.91 \pm 10.19$ & $64.87 \pm 8.89$ & $<0.001$ \\
\hline Periodic limb movement index & $12.08 \pm 22.01$ & $3.52 \pm 6.72$ & 0.001 \\
\hline $\mathrm{N} 1$ (min) & $7.80 \pm 7.26$ & $6.21 \pm 7.36$ & $<0.001$ \\
\hline $\mathrm{N} 2$ (min) & $62.67 \pm 13.04$ & $55.24 \pm 10.34$ & $<0.001$ \\
\hline $\mathrm{N} 3(\min )$ & $16.39 \pm 10.10$ & $21.45 \pm 8.51$ & $<0.001$ \\
\hline $\operatorname{REM}(\min )$ & $13.64 \pm 7.78$ & $17.43 \pm 6.23$ & $<0.001$ \\
\hline
\end{tabular}




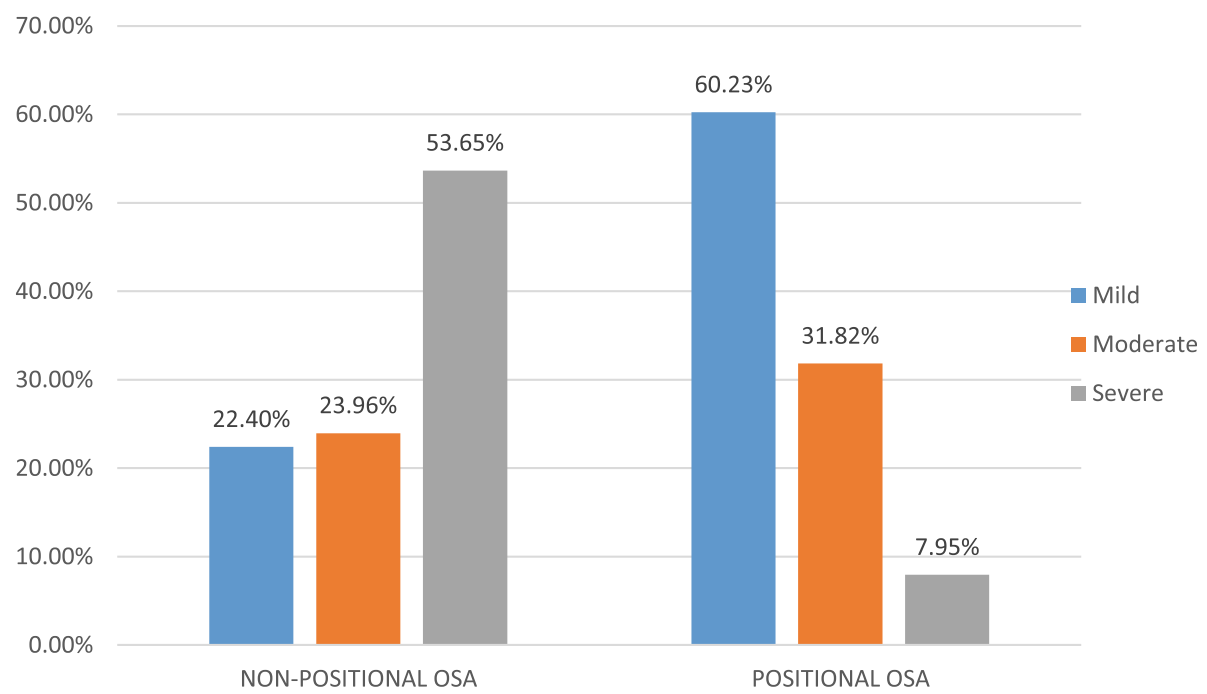

Fig. 1 Disease severity in positional and non-positional OSA groups

patients in our country, 118 (51.3\%) of the patients were identified as non-positional OSA and $112(48.7 \%)$ as positional OSA [4]. In our study, $31.43 \%$ of the OSA patients had positional OSA, while $68.57 \%$ of them had non-positional OSA. The rates were compatible with the literature.

In a study comparing the demographic characteristics of positional OSA and non-positional OSA patients, it was determined that age, gender, weight, height, BMI, and Epworth Sleepiness Scale were similar, and the patients with positional OSA had a shorter neck circumference $[10,11]$. In a study conducted on 3214 patients, it was revealed that the patients with positional OSA were younger and had lower BMI [13]. Yosunkaya et al. also revealed that the BMI and neck circumference values were lower in positional OSA patients [4]. Similarly, in our study, it was detected that the positional OSA patients were younger, had less BMI, and shorter neck circumference than the non-positional OSA patients. Patients admitted to sleep outpatient clinic wait a long time for polysomnography examination. During this time, position treatment may be recommended not to increase severity of disease.

Obesity is an important factor for OSA, and it has been reported that the frequency of positional OSA decreases with increased BMI $[14,15]$. In our study, it was determined that BMI was lower in patients with positional OSA. Similarly, Oksenberg et al. detected positional OSA at higher rates in non-obese patients (BMI $<30$ ), while non-positional OSA was found more frequently as weight increased [8]. Similarly, in another study conducted on 278 patients, it was found that the positional group was younger; BMI and neck circumference were also lower compared to the non-positional group [16]. In another study conducted in Korea, BMI was determined to be lower in the positional group compared to the non-positional group [17].

In the study conducted by Mohsenin et al., it was found that the number of males was higher in the nonpositional group compared to the positional group [18]. In the study conducted by Yosunkaya et al., males were more common in both groups; however, there was no difference between the positional group and nonpositional group in terms of gender. Similarly, in our study, there was no difference between the positional group and non-positional group in terms of gender. In another study, it was revealed that the gender distribution in the positional group was similar to the nonpositional group [11].

When the polysomnographic parameters were examined in our study, it was determined that there was a statistically significant difference between the positional group and non-positional group in terms of sleep efficiency, TST, stage 1 , stage 2 , stage 3 , REM period, and ODI. Oksenberg et al. also put forward that night sleep quality was better preserved in positional OSA patients. They also found that sleep efficiency and deep sleep (stages 3-4) percentages were significantly higher, and light sleep (stages 1-2) percentages were significantly lower in positional OSA patients, and there was no significant difference between the two groups in the REM period [8]. In another study conducted in our country, sleep efficiency was found to be significantly higher in patients with positional OSA [4]. Similarly, in our study, sleep efficiency was found to be statistically higher in the positional OSA patients compared to the non-positional patients. Moreover, stage 1 was lower, REM period and stage 3 were higher in the positional group, and the 
PLM index was also found to be low. In a 52-week retrospective study conducted according to home polysomnography records, it was determined that $54.6 \%$ of the patients had positional OSA. These patients were found to be younger, had lower BMI, and oxygen saturation below $90 \%$ [19]. In the study conducted by Wang et al. on 372 patients, the ODI value was lower in the positional group compared to the non-positional group, and the percentage of sleep time with saturation below $90 \%$ was shorter [20].

In the study conducted by Richard et al., AHI was higher in the non-positional group [21]. In another study, it was revealed that the total AHI values were significantly lower in the positional OSA group, and the positional OSA frequency was higher in the mild OSA group compared to the moderate OSA group [13]. Nonpositional OSA was more commonly seen in patients diagnosed with severe OSA [6, 21, 22]. Similarly, in our study, it was determined that the severity of the disease was less in the positional group. In a study performed on 292 patients with severe OSA, it was found that $35 \%$ was positional, and the severity of the disease was found to be milder in the positional group [23].

The limitations of our study include the absence of a detailed ENT examination and the absence of subtypes in the positional group.

\section{Conclusions}

According to the results of this study, positional OSA is a very important condition presented in $31.43 \%$ of OSA patients. It was revealed that patients with positional OSA had mild disease, high sleep efficiency, and these patients were young, had less BMI, and short neck circumference. Hence, positional OSA should be evaluated as a different clinical type and appropriate treatment should be initiated accordingly. In clinical practice, if polysomnography appointment is planned long term to young patients who have obvious clinical symptoms and short neck, during this time position treatment may be recommended not to increase severity of disease. In this way, the emergence of complications in the early period can be prevented.

\begin{abstract}
Abbreviations
OSA: Obstructive sleep apnea; AHI: Apnea-hypopnea index; Al: Apnea index; PLM: Periodic limb movement index; ODI: Oxygen desaturation index; ASDA: American Sleep Disorders Association; BMI: Body mass index; TST 90: Percent sleep time spent with oxygen saturation $<90 \%$;

EEG: Electroencephalogram; EOG: Electroculogram; ECG: Electrocardiogram; EMG: Electromyogram; pO2: The mean partial pressure of oxygen; sO2: Mean oxygen saturation; HT: Hypertension; DM: Diabetes mellitus
\end{abstract}

\section{Acknowledgements}

The authors would like to thank Gulten Aktin Gungor for her invaluable help.

\section{Authors' contributions}

Conceived and designed the analysis: SBS and SC. Collected the data: SBS and SC. Contributed data or analysis tools: SBS and SC. Performed the analysis: SBS and SC. Wrote the paper: SBS and SC. All authors have contributed to, read, and approved the final manuscript for submission. The manuscript has not been published and is not being considered for publication elsewhere in whole or part in any language.

Funding

None.

\section{Declarations}

Ethics approval and consent to participate

It is not applicable.

Consent for publication

Patient consent has been obtained.

Competing interests

The authors declare that they have no competing interests.

Received: 26 May 2021 Accepted: 23 August 2021

Published online: 22 September 2021

References

1. Casale M, Pappacena M, Rinaldi V, Bressi F, Baptista P, Salvinelli F (2009) Obstructive sleep apnea syndrome: from phenotype to genetic basis. Curr Genomics. 10(2):119-126. https://doi.org/10.2174/138920209787846998

2. Acar B, Babademez MA, Karabulut H, Ciftci B, Gunbey E, Karasen RM (2009) Otorhinolaryngologic examination in obstructive sleep apnea syndrome: the correlation between the severity of sleep disorder and physical examination. Kulak Burun Bogaz Ihtis Derg 19(5):246-252

3. Çelen YT, Peker Y (2010) Obsrüktif Uyku Apnede Kardiyovasküler Hastalıklar. In: Özlü T, Metintaş M, Karadağ MAK (eds) Solunum Sistemi ve Hastalıkları, vol 2. İstanbul Tıp Kitabevi, İstanbul

4. Yosunkaya Ş, Öztürk K (2012) Pozisyonel Obstrüktif Uyku Apne Sendromlu Hastaların Klinik ve Polisomnografik Özellikleri. Solunum. 14(1):34-41. https:// doi.org/10.5505/solunum.2012.65477

5. Ursavaş A, Göktaş K, Sütçigil L, Özgen F (2004) Obstrüktif Uyku Apnesi Sendromu Olan Hastalarda Obezite ve Kardiyovasküler Hastalıkların Değerlendirilmesi. Türk Toraks Dergisi 5:079-083

6. Köseoğlu Hî, Köktürk O, Çiftçi TU, Etikan I (2013) The Importance of Sleep Position in Obstructive Sleep Apnea Syndrome. Turk Toraks

7. Camilo MR, Fernandes RM, Sander HH, Nobre F, Santos-Pontelli T, dos Santos AC, Araujo DB, Leite JP, Pontes-Neto OM (2012) Supine sleep and positional sleep apnea after acute ischemic stroke and intracerebral hemorrhage. Clinics. 67(12):1357-1360. https://doi.org/10.6061/clinics/2012 (12) 02

8. Oksenberg A, Silverberg DS, Arons E, Radwan H (1997) Positional vs nonpositional obstructive sleep apnea patients: anthropomorphic, nocturnal polysomnographic, and multiple sleep latency test data. Chest. 112(3):629639. https://doi.org/10.1378/chest.112.3.629

9. Iber C, Ancoli-Israel S, Chesson AL Jr, Quan SF, for the American Academy of Sleep Medicine (2007) The AASM manual for the scoring of sleep and associated events: rules, terminology and technical specifications, 1st edn. American Academy of Sleep Medicine, Westchester

10. Mador MJ, Kufel TJ, Magalang UJ, Rajesh SK, Watwe V, Grant BJ (2005) Prevalence of positional sleep apnea in patients undergoing polysomnography. Chest. 128(4):2130-2137. https://doi.org/10.1378/chest.128.4.2130

11. Teerapraipruk B, Chirakalwasan N, Simon R, Hirunwiwatkul P, Jaimchariyatam $N$, Desudchit T et al (2012) Clinical and polysomnographic data of positional sleep apnea and its predictors. Sleep Breath 16(4):1167-1172

12. Woong Sang Sunwoo S-LH, Kim S-W, Park SJ, Han DH, Kim JW, Lee CH, Rhee C-S (2012) Association between Positional Dependency and Obstruction Site in Obstructive Sleep Apnea Syndrome. Clin Exp Otorhinolaryngol. 5(4):218-221. https://doi.org/10.3342/ceo.2012.5.4.218

13. Guven SF, Ciftci B, Lakadamyali H, Ciftci TU (2013) The high dependency of supine position in obstructive sleep apnea. Saudi Med J 34(2):147-152. 233 96460

14. Lam JC, Sharma SK, Lam B (2010) Obstructive sleep apnoea: definitions, epidemiology \& natural history. Indian J Med Res 131:165-170 
15. Itasaka Y, Miyazaki S, Ishikawa K, Togawa K (2000) The influence of sleep position and obesity on sleep apnea. Psychiatry Clin Neurosci 54(3):340-341. https://doi.org/10.1046/j.1440-1819.2000.00705.x

16. Oulhaj A, Al Dhaheri S, Su BB et al (2017) Discriminating between positional and non-positional obstructive sleep apnea using some clinical characteristics. Sleep Breath 21(4):877-884. https://doi.org/10.1007/s11325017-1499-0

17. Lee SA, Paek JH, Chung YS, Kim WS (2017) Clinical features in patients with positional obstructive sleep apnea according to its subtypes. Sleep Breath 21(1):109-117. https://doi.org/10.1007/s11325-016-1379-z

18. Mohsenin V (2003) Effects of gender on upper airway collapsibility and severty of obstructive sleep apnea. Sleep Med 4(6):523-529. https://doi. org/10.1016/S1389-9457(03)00168-0

19. Di-Tullio F, Ernst G, Robaina G et al (2018) Ambulatory positional obstructive sleep apnea syndrome. Sleep Sci 11(1):8-11. https://doi.org/10.5935/19840063.20180003

20. Wang X, Luo J, Huang R, Yi X (2021) Preliminary study on clinical characteristics of Chinese patients with positional obstructive sleep apnea. Sleep Breath. https://doi.org/10.1007/s11325-021-02346-8

21. Richard W, Kox D, den Herder C, Laman M, van Tinteren H, de Vries N (2006) The role of sleep position in obstructive sleep apnea syndrome. Eur Arch Otorhinolaryngol. 263(10):946-950. https://doi.org/10.1007/s00405-0060090-2

22. Oksenberg A, Dynia A, Nasser K, Gadoth N (2012) Obstructive sleep apnoea in adults: body postures and weight changes interactions. J Sleep Res. 21(4): 402-409. https://doi.org/10.1111/j.1365-2869.2011.00988.x

23. Oksenberg A, Gadoth N, Töyräs J, Leppänen T (2020) Prevalence and characteristics of positional obstructive sleep apnea (POSA) in patients with severe OSA. Sleep Breath 24(2):551-559. https://doi.org/10.1007/s11325-01901897-1

\section{Publisher's Note}

Springer Nature remains neutral with regard to jurisdictional claims in published maps and institutional affiliations.

\section{Submit your manuscript to a SpringerOpen ${ }^{\circ}$ journal and benefit from:}

- Convenient online submission

- Rigorous peer review

- Open access: articles freely available online

- High visibility within the field

- Retaining the copyright to your article

Submit your next manuscript at $\boldsymbol{\nabla}$ springeropen.com 